\title{
Cancer: the word raises panic in patients and medics
}

\author{
Giovanni Codacci-Pisanelli medical oncologist \\ University of Rome "la Sapienza," Corso della Repubblica, 79 Latina, Italy
}

Should we rename low risk cancers? ${ }^{1}$ Words will not solve our problems, but they may help. Cancer has been defined as "the emperor of all maladies" and its name raises panic, which is by definition irrational and, as stated in dictionaries, "often causes wildly unthinking behaviour." This certainly happens in patients, but the same holds true for medical doctors and (sadly) for medical oncologists.

Medical oncologists tend to implement "guidelines" rigidly and seem to have no consideration for disease characteristics and for extension. Young colleagues know by heart all possible mutations in the EGF receptor in lung cancer but ignore the difference between a microscopic infiltrating breast tumour $(<1$ $\mathrm{mm}$ in size) and a $3 \mathrm{~cm}$ mass. They treat both conditions in the same way, because the oncological community and the guidelines it issues promote treatment (and overtreatment). ${ }^{2}$
I agree that education (both of patients and of specialists) is the true "cure" of panic, but limiting the use of this frightening word may reduce anxiety in patients and stubborn adherence to guidelines in oncologists: both to the benefit of all parties. This has already been implemented for breast lobular carcinoma in situ—widening this attitude will be of benefit.

Competing interests: None declared.

Esserman LJ, Varma M. Should we rename low risk cancers?BMJ 2019;364:k4699. 10.1136/bmj.k4699 30674473

2 National Comprehensive Cancer Network (NCCN). Clinical practice guidelines in oncology. Breast cancer. 2019. www.nccn.org

Published by the BMJ Publishing Group Limited. For permission to use (where not already granted under a licence) please go to http://group.bmj.com/group/rights-licensing/ permissions 